\title{
Influence of selected demographic factors on traumas in persons over 65 years of age reporting to the Hospital Medical Ward
}

\author{
Wpływ wybranych czynników demograficznych na urazy u osób po 65. roku życia \\ zgłaszających się do SOR
}

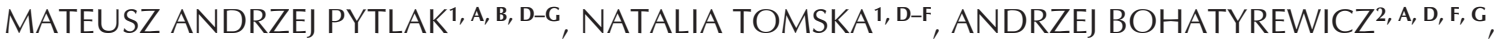
ALEKSANDRA RYŁ ${ }^{3, \mathrm{C}}$, IWONA ROTTER ${ }^{1, \mathrm{E}}$

\author{
${ }^{1}$ Independent Laboratory of Medical Rehabilitation, Pomeranian Medical University in Szczecin \\ ${ }^{2}$ Department of Orthopaedics, Traumatology and Locomotor System Oncology, Pomeranian Medical \\ University in Szczecin \\ ${ }^{3}$ Department of Histology and Developmental Biology, Pomeranian Medical University in Szczecin
}

A - Study Design, B - Data Collection, C - Statistical Analysis, D - Data Interpretation, E - Manuscript Preparation,

$\mathbf{F}$ - Literature Search, $\mathbf{G}$ - Funds Collection

Summary Background. Falls and traumas in elderly persons don't only result in health problems, but they also involve social and economic, psychological and political consequences. The most frequent trauma mechanisms in the elderly include: falls and traffic accidents.

Objectives. The aim of the study was to assess selected factors influencing the energy, type and area of a trauma incurred by elderly people.

Material and methods. A group of 108 patients aged 65-93 treated at the SPSK1 in Szczecin were tested by a diagnostic survey with the use of a questionnaire. The eligibility criteria included a trauma as a result of an accident, the age of the subject above 65 years of age and expressing written, voluntary and informed consent to participation in the study.

Results. 177 traumas were recorded in the analysed group of 108 patients. The most frequent traumas included fractures and contusions and the lower limbs and the left arm were the most frequently injured body parts. Men were more often injured during low-energy events. Patients more often had their upper body and left leg injured during low-energy events than during high-energy ones. In persons over 65 years of age, usually one fracture occurred during a low-energy accident.

Conclusions. The most common result of injuries among people aged 65+ admitted to the emergency department are fractures. With age the number of LET increases and the number of HET decreases. It's necessary therefore to create an appropriate health policy covering education for elderly people and their families to prevent injuries of low energy content.

Key words: falls, elderly, injuries.

Streszczenie Wstęp. Upadki i urazy osób starszych powodują nie tylko obciążenie zdrowotne, ale są związane z konsekwencjami społeczno-ekonomicznymi, psychologicznymi, ekonomicznymi i politycznymi. Najczęstsze mechanizmy urazów u osób starszych to upadek oraz wypadki komunikacyjne.

Cel pracy. Ocena wybranych czynników wpływających na energetyczność, rodzaj i obszar doznanego urazu u osób starszych. Materiał i metody. Badaniu sondażem diagnostycznym, metodą ankiety poddano grupę 108 pacjentów w wieku 65-93 lat, leczonych w SPSK1 w Szczecinie. Kryteriami kwalifikującymi było doznanie urazu w wyniku sytuacji losowej, wiek badanego powyżej 65. roku życia oraz wyrażenie pisemnej, dobrowolnej i świadomej zgody na przeprowadzenie badania.

Wyniki. W analizowanej grupie 108 pacjentów zanotowano 177 urazów. Najczęstszym rodzajem urazu były złamania oraz stłuczenia, a uszkodzaną okolicą ciała były obie dolne kończyny oraz górna kończyna lewa. Czynnikiem wpływającymi na rodzaj doznanego urazu była płeć. Kobiety częściej doznawały skręceń niż mężczyźni. Mężczyźni częściej doznawali urazów w trakcie zdarzenia o niskiej energetyczności. Obrażeń tułowia i kończyny dolnej lewej pacjenci częściej doznawali przy zdarzenia o niskiej energetyczności niż o wysokiej. U osób po 65. roku życia w trakcie wypadku o niskiej energetyczności najczęściej dochodziło do jednego złamania. Wnioski. Najczęstszym skutkiem urazów wśród osób w wieku $65+$ zgłaszających się do SOR są złamania. Wraz z wiekiem rośnie liczba urazów niskoenergetycznych (LET), a zmniejsza się liczba urazów wysokoenergetycznych (HET). Dlatego jest konieczne stworzenie odpowiedniej polityki zdrowotnej, obejmującej edukację dla osób starszych i ich rodzin, aby zapobiec urazom o niskiej energetyczności.

Słowa kluczowe: upadki, osoby w wieku podeszłym, urazy.

Fam Med Prim Care Rev 2016; 18(1): 49-53

\section{Background}

Owing to civilisation, progress in medicine and the growing interest in quality of life, in particular as regards the elderly, society is becoming healthier and lives longer. However, despite of all of these factors, population ageing is quite a severe and common problem of the contemporary world. Falls and traumas in elderly persons do not only result in health problems, but they also involve social and economic, psychological and political consequences [1-3]. The geriatric age is a natural stage of human ontogenesis, which is mostly characterised by reduced body performance 
and progressing degradation of physical and mental functions. As a result of these changes, multi-form limitations occur in basic everyday life activities, adaptation, locomotor activities and also in effective fulfilment of social roles. Persons at geriatric age are usually characterised by individual limitations and dysfunctions affecting individual functional systems of the body [3, 4].

It was shown that the occurrence of old-age diseases reduces the quality of life, deteriorating well-being and fitness of subjects. A healthy and active lifestyle involves undertaking activities, which are performed only by young people without considering the natural possibilities of their bodies that decrease with age [5].

The definition of trauma in the elderly raises a lot of controversy. According to WHO (World Health Organization), "a trauma is damage to tissue or an organ or a larger area of the body by a mechanical, thermal, chemical, electric factor, etc. Post-traumatic damage to the musculoskeletal system caused by mechanical damage is divided according to the type, degree and location of lesions to: closed contusion of soft tissues, wounds, fractures, sprains and dislocations. The most frequent trauma mechanisms in the elderly include: falls, traffic accidents, being hit by a vehicle" [6].

Physical activity of the elderly is connected with a higher risk of trauma, a higher percentage of complications after an accident, which, as a result, leads to a higher risk of death. A small trauma in an elderly person may involve physiological changes [7-10]. Involution processes influence the impairment of the functions of the postural and motor systems, which determine the stability of the posture. This stability is the resistance of the posture to endogenous and exogenous interferences, which have their sources in environmental activities and the body's interactions with the environment [2]. Falls of geriatric persons are caused by many factors. Their main causes include changes in the walking pattern, the condition of the cardiovascular and respiratory systems and the labile compensation mechanism during locomotor activities. Additional factors, which predispose to traumas, involve a lack of physical and mental fitness, chronic diseases, side effects of pharmacotherapy, earlier episodes of falls as well as no help from other people in the performance of everyday activities.

Orthostatic hypotony is connected with a change in the body position. It can be defined as a decrease by $20 \mathrm{~mm}$ $\mathrm{Hg}$ in the values of the systolic and diastolic pressure [4]. A sudden decrease in the blood pressure in an elderly person may induce stupor, dizziness and, as a result, an uncontrolled fall during a dynamic change of position. Research shows that such a situation applies to approx. $17-20 \%$ of hospitalised patients and approx. 33\% of elderly people who live on their own [11]. 50\% of falls result in traumas, including severe traumas in 10-15\% of patients [12]. Falls still occur most frequently during the performance of everyday activities [13]. Elderly persons often cause or are victims of traffic accidents, which almost always is a cause of trauma. There are numerous reports in the available literature about longer response times to stimuli, which increases the risk of late responses to hazards [14].

The most frequent traumas in the elderly include:

- rib fractures,

- head traumas/subdural haematomas,

- $\quad$ spine injuries/fractures,

- fractures of the proximal femur epiphysis,

- $\quad$ fractures of the distal part of the radius [5].

Over a half of geriatric patients do not fully recover after an accident and it can be observed that subsequent fractures in the same area occur in some of them [15].

As society is ageing, geriatric age problems will affect a growing percentage of the population. Testing factors, which influence trauma, is an important aspect of trauma prevention [16].

\section{Objectives}

The aim of the study was to assess selected demographic determinants influencing the energy, type and area of a trauma incurred by elderly people.

\section{Material and methods}

A group of 108 patients aged 65-93 (mean \pm standard deviation; $73.71 \pm 7.19$ ) were tested by a diagnostic survey with the use of a questionnaire. The patients were hospitalised at the Clinic of Orthopaedics, Traumatology and Oncology of the Musculoskeletal System at Independent Public Clinical Hospital No. 1 (SPSK1) in Szczecin after prior preliminary diagnosis and/or after receiving care on an outpatient basis at the Emergency Ward of the same hospital. The eligibility criteria for the study included a trauma as a result of an accident which occurred from 1.02.2013 to 31.12 .2014 , the age of the subject above 65 years of age and expressing written, voluntary and informed consent to the participation in the study. An anonymous questionnaire was completed by the patients on their own or with the assistance of an interviewer due to limitations resulting from the trauma or accompanying diseases (e.g. visual impairment). The questions included basic information, such as date of birth, gender, weight and height, from which the BMI was calculated. The BMI values were interpreted in a classical manner, according to $\mathrm{WHO}$ guidelines for adult persons: < 18.5 underweight 18.5-24.9 normal, 25-29.9 underweight, 30-39.9 obesity and > 40 severe obesity.

Another group of questions concerned the injured body area and the type of injury. Body areas were divided into lower and upper limbs, right and left ones, the head and the upper body. The types of injuries included fractures, nondisplaced fractures, dislocations, contusions, sprains, ruptures, pulls and wounds. The patients were also asked about their marital status (single, married, divorced, widow/widower), education (primary, vocational, secondary, higher) and income (below PLN 500, from 500 to 1000, from 1000 to 2000 , above 2000 a month per family member).

The surveyed patients also provided the date and mechanism of the trauma from which the researcher defined the day of the week of the trauma and its energy level. The energy of the trauma was divided into high (HET - high energy trauma), low (LET- low energy trauma) and difficult to define. High energy was marked for patients who incurred a trauma with a force higher than a fall from approx. 4 metres (13 feet) or participated in a traffic accident in a car moving at a speed of above $64 \mathrm{~km} / \mathrm{h}$ (40 mph), a motorcycle moving at a speed of above $32 \mathrm{~km} / \mathrm{h}$ (20 mph), a bicycle moving at a speed above $16 \mathrm{~km} / \mathrm{h}(10 \mathrm{mph})$ and for pedestrians and cyclists hit by cars and who are travelling faster than $8 \mathrm{~km} / \mathrm{h}$. Low energy was marked for patients who incurred a trauma as a result of: a fall from a height below 4 metres, a fall from stairs, participation in a traffic accident at speeds lower than those for high-energy traumas and patients who participated in a fight [17].

Traumas with unknown aetiology or difficult to classify were marked as "difficult to define". There were only 3 such persons and they were excluded from the study.

\section{Statistical analysis}

Statistical analysis was performed using the SPSS Statistics software, version 17.0. The following tests were used in the study: chi-square with Yates' correction, Kruskal-Wallis and $U$ Mann Whitney and the $t$-Student tests. The significance level of $p \leq 0.05$ was considered to be statistically significant. 


\section{Results}

108 persons above 65 years of age took part in the study. The structure of the group presented in Tables 1 and 2. The numbers of individual types of traumas and injured body areas are presented in Figures 1 and 2.

\begin{tabular}{|c|c|c|c|c|c|}
\hline & Distance & $\begin{array}{l}\text { Mini- } \\
\text { mum }\end{array}$ & $\begin{array}{l}\text { Maxi- } \\
\text { mum }\end{array}$ & Average & $\begin{array}{l}\text { Standard } \\
\text { deviation }\end{array}$ \\
\hline Age & 28.00 & 65.00 & 93.00 & 73.71 & 7.19 \\
\hline Weight & 64.00 & 41.00 & 105.00 & 70.37 & 12.92 \\
\hline
\end{tabular}

\section{Table 2. Statistical characteristics of the study group}

\section{$(n=108)$}

\begin{tabular}{|c|c|c|c|}
\hline $\begin{array}{l}\text { Analyzed } \\
\text { feature } \\
\end{array}$ & Levels & Frequency & $\begin{array}{l}\text { Percentage } \\
\text { of total }\end{array}$ \\
\hline \multirow{2}{*}{$\begin{array}{l}\text { Energetic } \\
\text { injury }\end{array}$} & low energy trauma & 91 & 84.30 \\
\hline & high energy trauma & 17 & 15.70 \\
\hline \multirow[t]{2}{*}{ Gender } & female & 76 & 70.40 \\
\hline & male & 32 & 29.60 \\
\hline \multirow[t]{4}{*}{ Marital status } & single & 3 & 2.80 \\
\hline & married & 48 & 44.40 \\
\hline & widow & 48 & 44.40 \\
\hline & divorce & 9 & 8.30 \\
\hline \multirow[t]{6}{*}{ Education } & primary & 26 & 24.10 \\
\hline & high school & 15 & 13.90 \\
\hline & vocational & 13 & 12.00 \\
\hline & technical & 26 & 24.10 \\
\hline & $\begin{array}{l}\text { post secondary } \\
\text { school }\end{array}$ & 5 & 4.60 \\
\hline & higher & 23 & 21.30 \\
\hline \multirow{2}{*}{$\begin{array}{l}\text { Professional } \\
\text { status }\end{array}$} & pensioner & 99 & 91.70 \\
\hline & employed & 9 & 8.30 \\
\hline \multirow[t]{4}{*}{ Wealth } & $\begin{array}{l}<500 \text { PLN } \\
(<135 \$)\end{array}$ & 4 & 3.70 \\
\hline & $\begin{array}{l}500-1000 \text { PLN } \\
(135-270 \$)\end{array}$ & 16 & 14.80 \\
\hline & $\begin{array}{l}1000-2000 \text { PLN } \\
(270-540 \$)\end{array}$ & 62 & 57.40 \\
\hline & $\begin{array}{l}>2000 \text { PLN } \\
(>540 \$)\end{array}$ & 26 & 24.10 \\
\hline \multirow{7}{*}{$\begin{array}{l}\text { Place of } \\
\text { residence }\end{array}$} & village & 10 & 9.30 \\
\hline & city $<5000$ & 4 & 3.70 \\
\hline & city 5000-20000 & 1 & 0.90 \\
\hline & city $20000-50000$ & 2 & 1.90 \\
\hline & $\begin{array}{l}\text { city } 50000- \\
-100000\end{array}$ & 10 & 9.30 \\
\hline & $\begin{array}{l}\text { city } 100000- \\
-200000\end{array}$ & 3 & 2.80 \\
\hline & city > 200000 & 78 & 72.20 \\
\hline
\end{tabular}

177 traumas were recorded in the analysed group of patients. The most frequent traumas included fractures and contusions and both lower limbs and the left upper arm were the most frequently injured body areas.

A comparison of the energy level of the accident shows that men more often incurred traumas during low-energy events ( $p=0.023$ ) than during high-energy ones. Unmarried persons (widow/widower, single, divorced) more often had low-energy traumas than married persons $(p=0.07)$, borderline significance. Upper body and left leg injuries were more often incurred during low-energy events than high-energy ones $(p=0.01)$. In persons over 65 years of age, usually one fracture occurred during a low-energy accident $(p=0.03)$. In the study group, sprains occurred more often in women than in men. The only group of subjects, in which the day of the week may have influenced the occurrence of a trauma, are single persons. They most often incurred traumas on Wednesdays ( $p=0.012)$. The results of the study show that persons with the monthly income per family member of PLN $<1000-2000$ are less exposed to head injuries than patients from other income groups $(p=0.01)$.

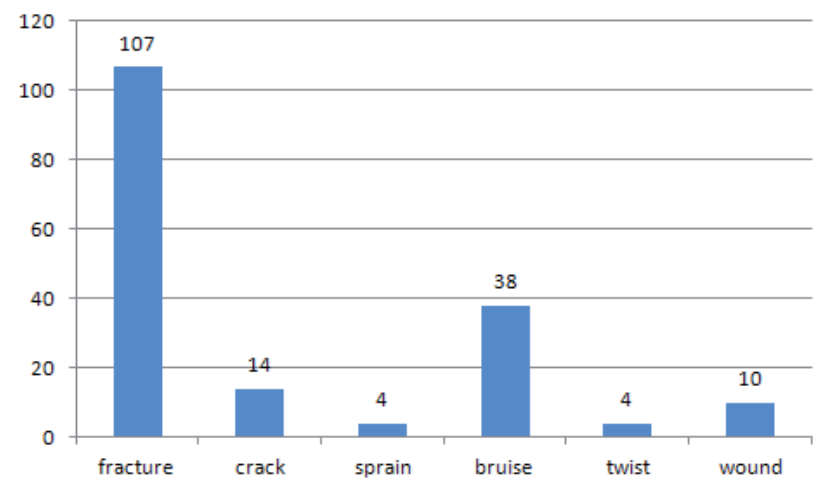

Figure 1. The number of analysed traumas in patients taking part in the study

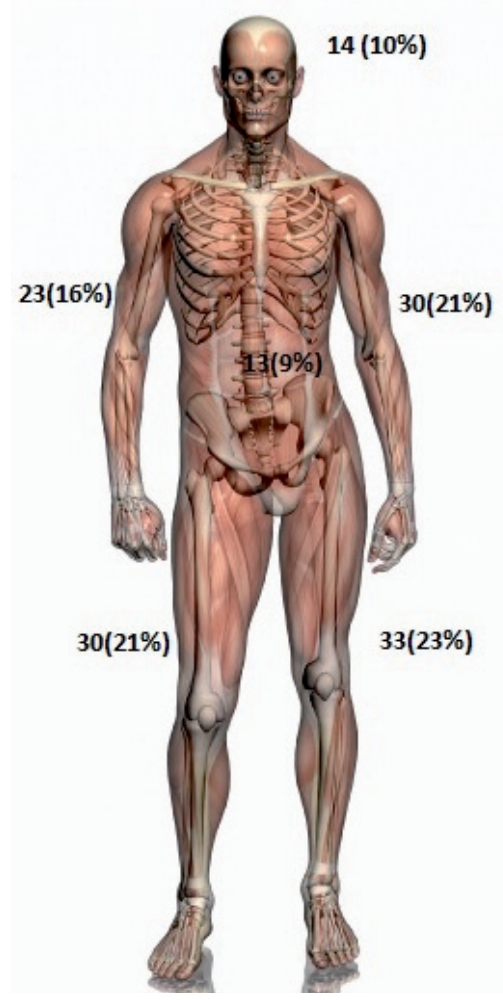

Figure 2. The number and distribution of traumas in individual parts of the body of patients taking part in the study. (Compilation based on the source: http://linemed.pl/nhealth_guide/details/id,1437. At 13-05-2015)

The statistical analysis of BMI values did not show any influence of this parameter on the location and type of injury in the elderly.

The average age of persons in whom low-energy traumas occurred more often was 74.3 years of age. For high- 
energy traumas, the average age of patients was 70.1 years of age. The average weight of patients with high-energy traumas was $77.9 \mathrm{~kg} \pm 15.0($ mean $\pm \mathrm{SD})$.

\section{Discussion}

The high number of contusions may result from the fact that elderly persons incurred additional contusions in other body areas. Also, a high number of fractures in the study group may result from the fact that patients come to the doctor only with severe traumas and from reduced bone mass and density, which predispose to bone traumas rather than soft tissue injuries. A high referral level of the hospital, where the research was conducted, is another factor that may influence this condition. Despite the fact that the results presented are comparable with the results obtained by Borgstedt-Risberg et al., which show that the majority of accidents occur at home or near home $(80 \%$ in the $85-89$ age group). Fractures were found in $51 \%$ of patients following a fall, contusions, such as bruises, small subcutaneous haematomas and compression injuries, were found in 23\% and open wounds in $12 \%$ of the patients [17]. This confirms the thesis that even a low-energy trauma can be very dangerous for an elderly person. The level of danger increases proportionately to the elderly person's age [18].

Statistical analysis confirmed that the body build is not related to the traumas incurred by elderly patients. Contemporary scientists from the Deakin University in Melbourne, Australia, prove beneficial effects to obesity in elderly persons. As explained by the authors of a study published in the "American Journal of Clinical Nutrition", persons over 65 years of age lived longer with BMI between 23 and 33. They assumed that the ideal body weight of an elderly person can be much higher than the weight recommended by $\mathrm{WHO}$ (i.e.18.5-25). This may be very controversial as potentially, obese people live generally shorter due to their unfitness. Additionally, they have accidents more often and their recovery after a trauma is slower [19].

Zak in his studies on the potential risk of accidental falls in elderly people writes that the frequency of falls oscillates around 33\% among outpatients, 20\% among hospitalised patients and $45 \%$ among nursing home residents. Also, $10-15 \%$ of falls, which cause severe life-threatening trauma, must be mentioned. In his research, fractures in the upper part of the femur are the most frequent results of falls $(50 \%)$ - his study group consisted of nursing home residents. According to Swedish statistics, as many as $10 \%$ of falls of elderly persons result in severe traumas, including $1-2 \%$ of cases of the femur neck $[20,21]$.

The data obtained provides information on the circumstances of the trauma (i.e. the location, time, situation) within each of the tested groups, which facilitates the development of appropriate preventive measures. Research, which deals with the issue of accidental falls of elderly persons and accompanying costs of medical care incurred by the public health care system, is still very rare in Poland; however, further research and detailed investigation deserve special attention [21, 22].

It is commonly thought that with the increase of transferred energy the complexity of trauma increases as well. Our studies show that more often results for LET and HET are fractures. The conclusion can be that not energy of trauma but age, and therefore quality of tissue have impact on the type of injury. The same conclusion is shown in the results of Kodde and collaborators, examining factors affecting the trauma in patients after fractures of the radial head [23].

Significant difference in the number of patients of low and high energy injuries may be seen for several reasons. One of these is the mortality rate of people experiencing high-energy trauma.

Studies conducted by Arslan ED and co-workers show that $78 \%$ of deaths from random injuries happen as a result of traumas with a high energy content [24].

Another factor may be smaller mobility capacity in older age which causes a reduction of exposure to potentially high-energy incident.

As shown by research by Żak and Krekor, balanced training using various types of exercises, both conventional and derived from the Far East performed on special platforms reduces the risk and consequences of potential accidents (post-fall stress) $[25,26]$. The use of hip protection devices seems to be a good preventive measure for the very common and dangerous femur neck fracture.

The analysis of factors influencing trauma occurrence in elderly patients is a significant factor not only for social and ethical reasons, but also for economic reasons. Treatment of diseases, traumas and complications after traumas generates enormous costs. As a result, it is necessary to continue the research on a larger number of patients.

\section{Conclusions}

The most common result of injuries among people aged $65+$ admitted to the emergency department are fractures. With age the number of low-energy trauma (LET) increases and the number of high-energy trauma (HET) decreases. It is necessary therefore to create an appropriate health policy covering education for elderly people and their families in order to prevent injuries of low energy content.

\section{Restrictions}

The study may relate only to hospitals with high referentiality in big cities above 200000 inhabitants. The sample was collected on an arbitrary selection. Due to the lack of own hospital statistics on the mechanism and energy content of injuries we are not able to determine the total number of hospitalized patients in a given period.

Source of funding: This work was funded by the "Young Researcher" Project no. MB-315-134/14.

Conflict of interest: The authors declare no conflict of interests.

\section{References}

1. Chang TT, Schecter WP. Injury in the elderly and end-of-life decisions. Surg Clin North Am 2007; 87(1): $229-245$.

2. Błaszczyk JW, Czerwosz L. Stabilność posturalna w procesie starzenia. Gerontol Pol 2005; 13(1): 25-36.

3. Szpringer M, Wybraniec-Lewicka B, Czerwiak G, i wsp. Upadki i urazy wieku geriatrycznego. Stud Med 2008; 9: 77-81.

4. Klukowski K. Zdolność wysiłkowa osób w starszym wieku. W: Zembaty A, red. Kinezyterapia. T. II. Kraków: Kasper; 2003: 152-157.

5. Baczuk L. Urazy u osób w wieku starszym. Post Nauk Med 2008; 12: 793-796.

6. Gawroński W. Uraz, obrażenie a kontuzja. Med Sportiva 1998; 2(4): 343-344.

7. Gubler KD, Davis R, Koepsell T, et al. Long-term survival of elderly trauma patients. Arch Surg 1997; 132: 1010-1014. 
8. Criddle LM. Outcome in the injured elderly: where do we go from here? J Emerg Nurs 2006; 32(3): 234-240.

9. McMahon DJ, Shapiro MB, Kauder DR. The injured elderly in the trauma intensive care unit. Surg Clin North Am 2000; 80(3): 1005-1019.

10. Grossman MD, Miller D, Scaff DW, et al. When is an elder old? Effect of preexisting conditions on mortality in geriatric trauma. J Trauma 2002; 52(2): 242-246.

11. Wdowiak L, Budzyńska-Kapczuk A. Wielkie problemy geriatryczne - zaburzenia mobilności, równowagi i upadki. Pielęg Położ 2004; 46(8): 20-21.

12. Skalska A, Żak M. Upadki - ocena ryzyka, postępowanie prewencyjne. Stand Med 2007; 4: 156-163.

13. Gates S, Fischer JD, Cooke MW, et al. Multifactorial assessment and targeted intervention for preventing falls and injuries among older people in community and emergency care settings: systematic review and meta-analysis. BMJ 2008; 336(7636): 130-133.

14. Stevenson J. When the trauma patient is elderly. J Perianasth Nurs 2004; 19(6): 392-400.

15. Radcliff TA, Henderson WG, Stoner TJ, et al. Patient risk factors, operative care and outcomes among older community-dwelling male veterans with hip fracture. J Bone Joint Surg Am 2008; 90(1): 34-42.

16. Nijboer J, van der Sluis CK, Dijkstra P, et al. The value of the trauma mechanism in the triage of severely injured elderly. Eur J Trauma Emerg Surg 2009; 35(1): 49-55.

17. American College of Surgeons Committee on Trauma (Amendments to). Resources for optimal care of the injured patient: 2000. Chicago: American College of Surgeons; 2000.

18. Edbom-Kolarz A, Marcinkowski JT. Upadki osób starszych - przyczyny, następstwa, profilaktyka. Hygeia Public Health 2011; 46(3): 313-318.

19. Winter JE, Maclnnis RJ, Wattanapenpaiboon N, et al. BMI and all-cause mortality in older adults: a meta-analysis. Am J Clin Nutr 2014; 99(4): 875-890.

20. Żak M. Upadki osób starszych - analiza zagrożeń na podstawie obserwacji prowadzonych w latach 1994-2001. Prz Lek 2002; 59(4-5): 304-307.

21. Sadigh S, Reimers A, Andersson R, et al. Falls and fall-related injuries among the elderly: a survey of residential-care facilities in a Swedish municipality. J Community Health 2004; 29(2): 129-140.

22. Zak M, Namysl M. Assessment of potential risk factors for falls in the frail elderly versus individual mobility considerations. New Medicine 2003; 4: 130-132.

23. Kodde IF, Kaas L, van Es N, et al. The effect of trauma and patient related factors on radial head fractures and associated injuries in 440 patients. BMC Musculoskelet Disord 2015; 16: 135.

24. Arslan ED, Kaya E, Sonmez M, et. al. Assessment of traumatic deaths in a level one trauma center in Ankara, Turkey. Eur J Trauma Emerg Surg 2015; 1: 319-323.

25. Żak M. Rehabilitacja w procesie leczenia osób starszych. Gerontol Pol 2000; 8(1): 12-18.

26. Krekora K, Czernicki J. Biologiczne sprzężenie zwrotne w rehabilitacji chorych po udarze mózgu. Rehabil Med 2005; 9(3): $32-36$.

Address for correspondence:

Mgr Mateusz Andrzej Pytlak

Samodzielna Pracownia Rehabilitacji Medycznej PUM

ul. Żołnierska 54

71-210 Szczecin

Tel.: +48 500 030-155

E-mail:pytlak@pum.edu.pl

Received: 15.05.2015

Revised: 10.08.2015

Accepted: 10.08.2015 